\title{
The effect of different combinations of dietary energy and protein on the composition of ostrich eggs
}

\author{
Z. Brand ${ }^{1,2}$, T.S. Brand ${ }^{1,3 \#}$ and C.R. Brown ${ }^{4 *}$ \\ ${ }^{1}$ Ostrich Research Unit, Elsenburg, Agricultural Research Centre, Private Bag X1, Elsenburg 7607, South Africa \\ ${ }^{2}$ Klein Karoo Co-operative, P.O. Box 241, Oudtshoorn 6620 South Africa \\ ${ }^{3}$ Department of Animal Science, University of Stellenbosch, Stellenbosch 7600, South Africa \\ ${ }^{4}$ Department of Zoology and Entomology, Rhodes University, Grahamstown 6139, South Africa
}

\begin{abstract}
Nutrition of breeding female birds can influence egg quality and is therefore extremely important for the development of the embryo and the successful hatching of a high quality chick. We investigated the effect of combining different levels of dietary energy and protein, with accompanied amino acid levels, in the diets of female ostriches on the composition of their eggs. Ninety pairs of breeding ostriches were divided randomly into nine groups of 10 pairs per group in a factorial design with three energy and three protein levels. The groups were fed diets with levels of 7.5, 8.5 and $9.5 \mathrm{MJ}$ metabolisable energy $/ \mathrm{kg}$, each combined with each one of three protein levels 105,120 and $135 \mathrm{~g} / \mathrm{kg}$ respectively. Fresh eggs were collected from each group at the end of the breeding season and the albumen and yolk separated and analysed for protein and lipid content and for amino acid and mineral composition. No significant interaction between energy and protein levels occurred. Despite some differences in egg composition and amino acid concentrations, different dietary energy and protein levels for the most part had little or no effect on the composition of ostrich eggs.
\end{abstract}

Keywords: Breeding ostriches, nutrition, energy, protein, amino acids, egg composition

${ }^{\#}$ Corresponding author. E-mail: tersb@elsenburg.com

*Present address: Hartpury College, Hartpury, Gloucestershire, GL19 3BE, England

\section{Introduction}

Apart from physical factors like temperature, water vapour pressure gradients and turning, bird embryos are entirely dependent upon the contents of the preformed egg for successful growth and development (Whitehead, 1989). The yolk and albumen in the egg supply the developing embryo with nutrients, water and minerals for normal growth. Yolk is an important nutritional component of the avian egg because it contributes $75 \%$ of the joules and provides all the lipids, and thus the energy, for the developing embryo (Noble et al., 1996), as well as being an important source of protein (Deeming, 2002). The yolk also provides all or most of the minerals, vitamin A and thiamine, and yolk lipids provide a range of essential components for tissue development and function. The albumen is an important reservoir for water, essential ions and protein, the latter forming $99 \%$ of the dry matter of albumen and also having useful anti-microbial properties (Deeming, 1997; 2002).

Egg composition varies between avian species depending on the stage of development of hatchlings on the altricial-precocial continuum. Within a species, however, the number of eggs produced and their size and composition are variables that are affected by several factors, including the physical environment and the age, genetic background and nutrition of the hen (Badley, 1997). The nutrition of the breeding female in particular can influence many of these characteristics and is therefore extremely important for the development of the embryo and the successful hatching of a high quality chick. Protein content of food, rather than energy may be a limiting factor for egg formation in birds (Nager et al., 1997), but the role of dietary protein and energy levels in egg production and egg quality is equivocal.

Ostriches have been reared commercially in South Africa for over a century. After being laid, eggs are removed for artificial incubation and the females continue to lay eggs at a rate of approximately one every 25 days throughout the breeding season (June - January). The average weight of an ostrich egg is $1455 \mathrm{~g}$, which represents approximately $1.2 \%$ of the body weight of the adult female. This is similar to that of turkeys (approximately 1.0\%) but considerably less than the 3.5\% for chickens and the $8 \%$ for quail (Sales et al., 1996). Due to the fact that commercially farmed ostriches have an extended breeding season during which individual females may lay up to 50 or more eggs, nutrition may play a particularly important role in egg production. Nutrient deficiencies in the egg at laying may ultimately result in embryonic mortality and 
reduced hatchability or in poor quality hatchlings. Although there have been numerous studies on the effect of nutrition in poultry (Naber, 1979; Spratt \& Leeson, 1987; Barreto \& Ferreira, 1999a; Hammershøj \& Kjaer, 1998), there have been few reports of the effect of nutrition on egg quality and hatchability of ostrich eggs (Angel, 1993). We consequently assessed the influence of different dietary energy and protein levels, with accompanied relevant amino acid levels, on egg production and the composition of ostrich eggs.

\section{Materials and Methods}

Experimental birds used in the study were domesticated South African black ostriches. Management of the breeding flock and treatment of the eggs were described by Van Schalkwyk (1998). Ninety breeding pairs, consisting of one adult male and one adult female ostriches, were divided randomly into nine groups of 10 pairs per group, in a $3 \times 3$ factorial arrangement, with the breeding pair being the experimental unit. Each group represented a treatment combination (energy level x protein level), with 10 replicates (breeding pairs) per group. Hence, the factors tested were dietary energy and dietary protein, with accompanied relevant essential amino acid levels, respectively, each at three levels of inclusion, i.e. 7.5, 8.5 and $9.5 \mathrm{MJ}$ metabolisable energy (ME)/kg dry matter (DM), and 105,120 and $135 \mathrm{~g}$ crude protein $/ \mathrm{kg} \mathrm{DM}$, the latter with corresponding lysine levels of $4.9,5.9$ and $6.9 \mathrm{~g} / \mathrm{kg}$. The experiment was done at the Oudtshoorn experimental farm near Oudtshoorn, South Africa. The breeding pairs were kept in separate breeding pens of $50 \mathrm{~m}^{2}$ throughout the whole of the breeding season, and fed the experimental diets. Diet formulations were done according to requirement and raw material composition values presented in the Elsenburg Ostrich Feed Databases (Brand, 2000). The feeds were milled to pass through a 3-mm sieve and pelleted. The breeding birds were fed three times a week and each bird was given $2.5 \mathrm{~kg} \mathrm{DM} /$ day throughout the breeding season (June - January).

Eggs produced during the last month of the breeding season (January) were used for chemical analyses. Number of eggs produced at different dietary levels was discussed in detail by Brand et al. (2003). All egg components were studied raw to avoid changes in their composition that might be caused by boiling. The eggs were weighed to determine total egg weight, and the eggs were then frozen for easier separation of the yolk and albumen. After this, the eggs were broken to separate these components. The weight of the shell (including membranes), yolk and albumen was determined. The albumen and yolk were freeze-dried for 36 hours in a vacuum freeze-dryer to determine the dry weight. Protein content of albumen and yolk was determined using a Leco Nitrogen Analyser (Model FP 428) according to methods prescribed by the Association of Official Analytical Chemists (AOAC, 1995). Fat was extracted in petroleum ether using the Soxhlet method (AOAC, 1995). Ash content was determined following combustion at $500{ }^{\circ} \mathrm{C}$ in a muffled furnace for eight hours. The amino acids were analysed using the HPLC method (Einasson et al., 1983). Minerals were analysed by the standard AOAC methods (AOAC, 1975). Data were analysed according to a 3 (energy) x 3 (protein) factorial design with energy and protein levels featuring as main factors. Statgraphics statistical software (Statgraphics, 1991) was used to assess significant difference between treatment groups and interactions between energy and protein levels.

\section{Results}

No significant interactions were observed between energy and protein levels. The main effects of the different energy and protein levels in the diet are therefore presented separately. Different levels of dietary energy and protein had no effect on the physical characteristics of the eggs. Overall, the weight of eggs between diet groups ranged between 1347 and $1446 \mathrm{~g}$ and did not differ $(\mathrm{P}>0.50)$ due to dietary energy or protein levels (Table 1). There was also no significant difference in the weight of the shell and membranes or wet albumen and yolk weight of the eggs (Table 1) due to dietary treatment. Shell and membrane weight ranged from 276 to 295 g (approximately $20 \%$ of fresh egg weight), and albumen and yolk made up approximately $70 \%$ and $30 \%$ of the egg contents respectively.

Overall, water content comprised 47 to $48 \%$ of the yolk. Yolk water content in the case of females fed the low-energy diet averaged $47.0 \%$, which was slightly lower $(\mathrm{P}<0.01)$ than that for females fed the higher-energy diets, but yolk water content was not influenced by different levels of dietary protein (Table 2). Inorganic matter (ash) level of the yolks varied between 38 and $42 \mathrm{~g} / \mathrm{kg}$. Dietary protein had no significant effect on the inorganic content of the yolk. Crude protein and lipid concentrations of the yolk averaged about 320 and $570 \mathrm{~g} / \mathrm{kg}$, respectively, and did not differ significantly for females fed the different diets. 


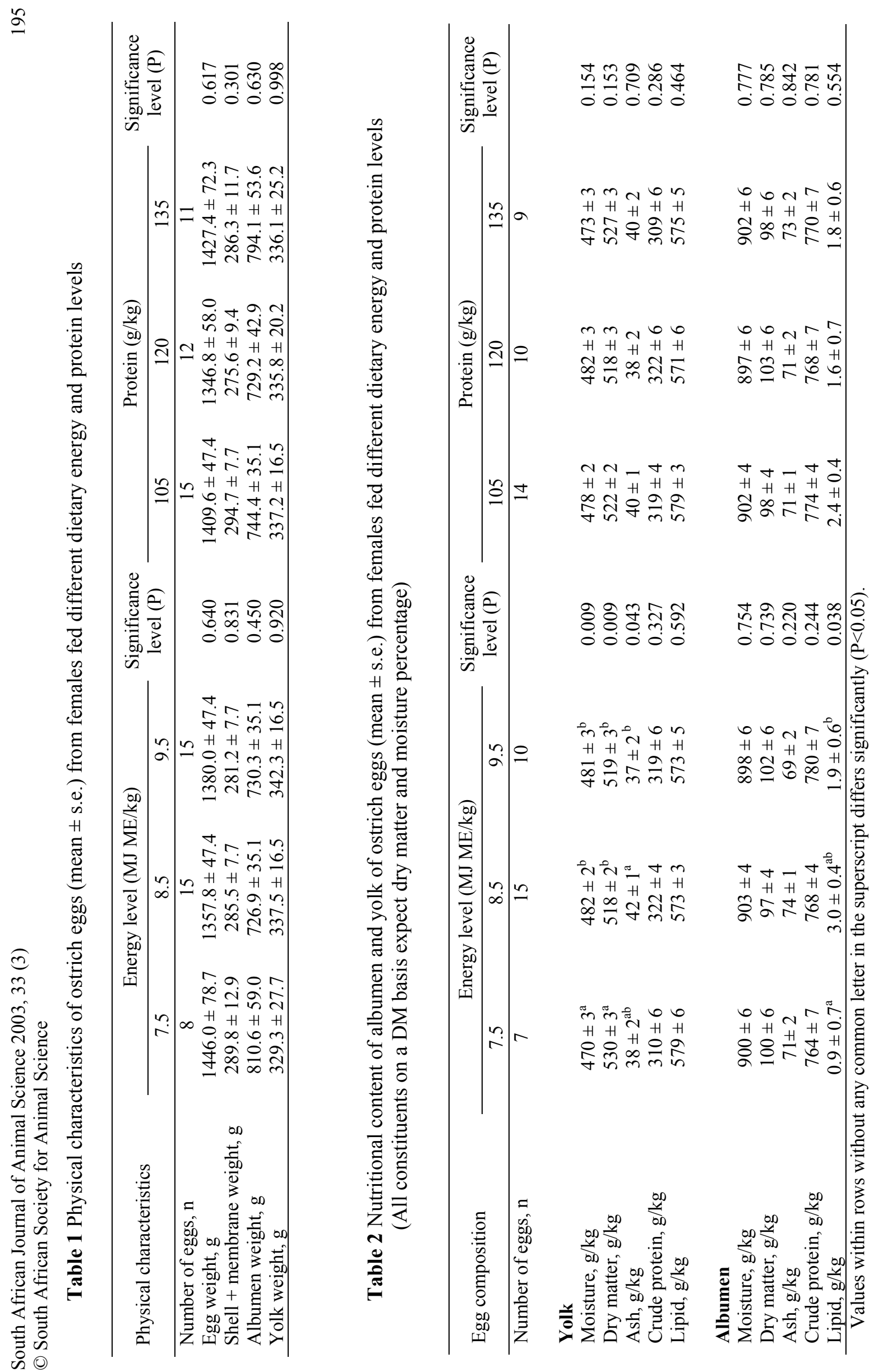

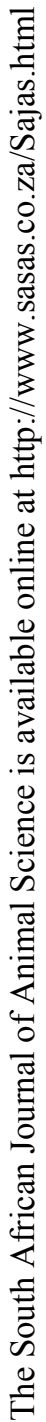


Water content of ostrich egg albumen averaged $90 \%$ and was not influenced $(\mathrm{P}>0.75)$ by dietary energy or protein levels (Table 2). About $76-78 \%$ was made up of protein, which was also not influenced $(\mathrm{P}>0.20)$ by dietary energy or protein levels (Table 2 ). Lipid made up only between 0.09 and $0.30 \%$ of the albumen and was lower in females fed the low-energy diet $(0.09 \%)$ compared with those fed the higherenergy diet $(\mathrm{P}<0.04)$. Different dietary protein levels, however, had no effect $(\mathrm{P}>0.50)$ on albumen lipid content (Table 2).

Amino acid concentrations in the albumen of ostrich eggs are shown in Table 3. Although concentrations of these were similar in eggs from females fed different dietary energy levels, some of the differences were nevertheless statistically significant.

The concentration of the essential amino acid, arginine, increased $(\mathrm{P}=0.001)$ with an increasing energy content of the diet, and threonine, phenylalanine and leucine tended to be highest in eggs from birds fed the highest dietary energy levels $(\mathrm{P}<0.03)$. Although several of the other amino acids also differed significantly (Table 3), there was no consistent relationship between energy level in the diet and amino acid concentration in the albumen. Different concentrations of dietary protein had no significant effect on the concentrations of amino acids in the albumen of ostrich eggs, except for arginine, which although significantly different $(\mathrm{P}=0.025)$ for the various diets, showed no consistent pattern (Table 3 ).

Mineral concentrations in the yolk and albumen of ostrich eggs are presented in Table 4 . With the exception of $\mathrm{Cu}$, dietary energy and protein levels did not significantly influence the concentrations of minerals in the yolk or albumen. The $\mathrm{Cu}$ concentration $(0.95 \mathrm{mg} / \mathrm{kg})$ was higher $(\mathrm{P}=0.03)$ in the egg yolk of birds fed the low-energy diet compared with those fed the higher-energy diets (about $0.66 \mathrm{mg} / \mathrm{kg}$ ). There was also a tendency for higher $\mathrm{Cu}$ concentrations $(0.80-0.87 \mathrm{mg} / \mathrm{kg})$ in eggs from birds fed the 105 and $120 \mathrm{~g}$ protein $/ \mathrm{kg}$ diets compared with birds fed the $135 \mathrm{~g}$ protein $/ \mathrm{kg}$ diet $(0.60 \mathrm{mg} / \mathrm{kg})$, but this difference was not statistically significant $(P=0.09)$. There were no significant differences in mineral concentrations in the albumen of birds fed different levels of dietary energy, and although there were significant differences in the albumen of birds fed different levels of dietary protein, these differences were small and showed no consistent pattern (Table 4). Of the eight minerals analysed, $\mathrm{P}, \mathrm{Mg}$ and Fe concentrations were higher in yolk than in albumen. The concentrations of $\mathrm{K}, \mathrm{Na}$, and $\mathrm{Mn}$ were higher in albumen than in yolk, and the concentrations of $\mathrm{Ca}$ and $\mathrm{Cu}$ were similar in yolk and albumen (Table 4).

\section{Discussion and Conclusions}

The shell of ostrich eggs contributes approximately $20 \%$ of the weight of the egg. This is proportionately more than for other species of birds (Deeming, 1997). Albumen contributes approximately $56 \%$ and yolk $24 \%$ of fresh egg weight. This is slightly higher and lower, respectively, than the values of $53.4 \%$ and $32.5 \%$ given by Sales et al. (1996). Albumen and yolk as a proportion of egg contents (70\% and $30 \%$ respectively) are similar to the $66 \%$ and $34 \%$ previously reported (Deeming, 1997). Neither dietary energy nor protein levels had any significant effect on the physical characteristics of ostrich eggs. This is also true, specifically, for the size and weight of poultry eggs (Morris, 1985). Similarly, several other studies have suggested that protein levels have no effect on egg production, egg composition and egg size of broiler breeder hens (Lopez \& Leeson, 1995; Barreto \& Ferreira, 1999a) or great tits (Parus major L.) (Nager et al., 1997). Barreto \& Ferreira (1999b) found that protein levels have no effect on yolk composition and Hanczakowski et al. (1998) found that different animal and plant proteins have only a minor effect on hen performance and no effect on yolk fatty acid composition of eggs produced by laying hens. These findings are consistent with the results of the present study, but are contrary to the results of several other studies. The proportion of albumen and albumen protein in eggs of cage-reared Starcross layers increased significantly with an increase in dietary protein levels, but was not influenced by changing dietary energy content (Uddin et al., 1997). Zebra finches (Taeniopygia guttata), whose diets were supplemented with protein, laid larger eggs with a greater proportion of yolk and albumen protein (Williams, 1996), and it has been suggested that dietary protein may be a direct and an indirect factor influencing the allocation of lipid and protein stores in laying birds (Carey, 1996). Egg weight and yolk content of broiler breeders also increased as dietary protein and energy increased (Spratt \& Leeson, 1987). In contrast, increasing the dietary amino acid and protein resulted in an increase in egg weight, but a decrease in albumen quality in laying hens (Hammershøj \& Kjaer, 1998). In the cage-reared Starcross layers, egg weight increased, but the proportion 


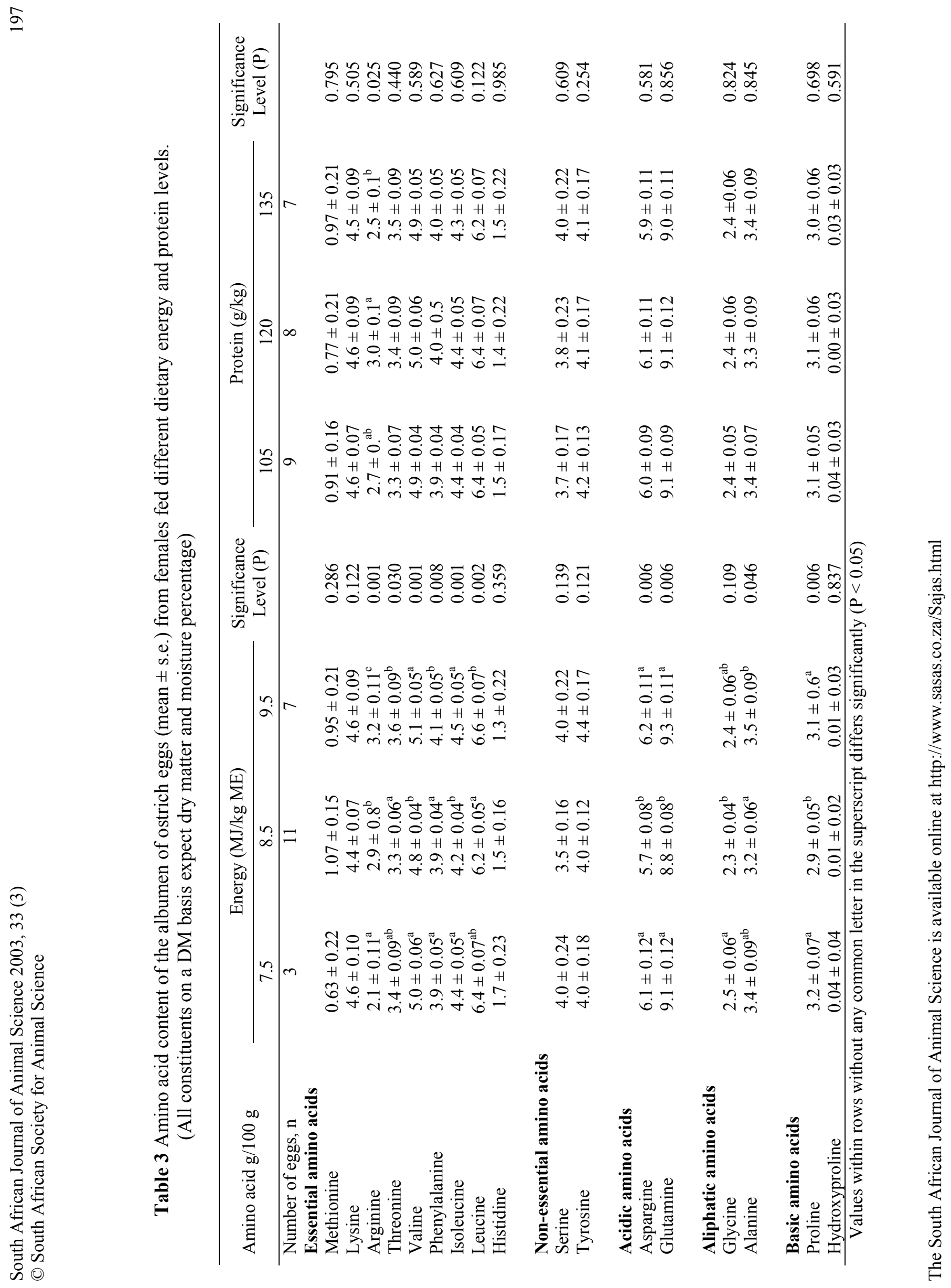




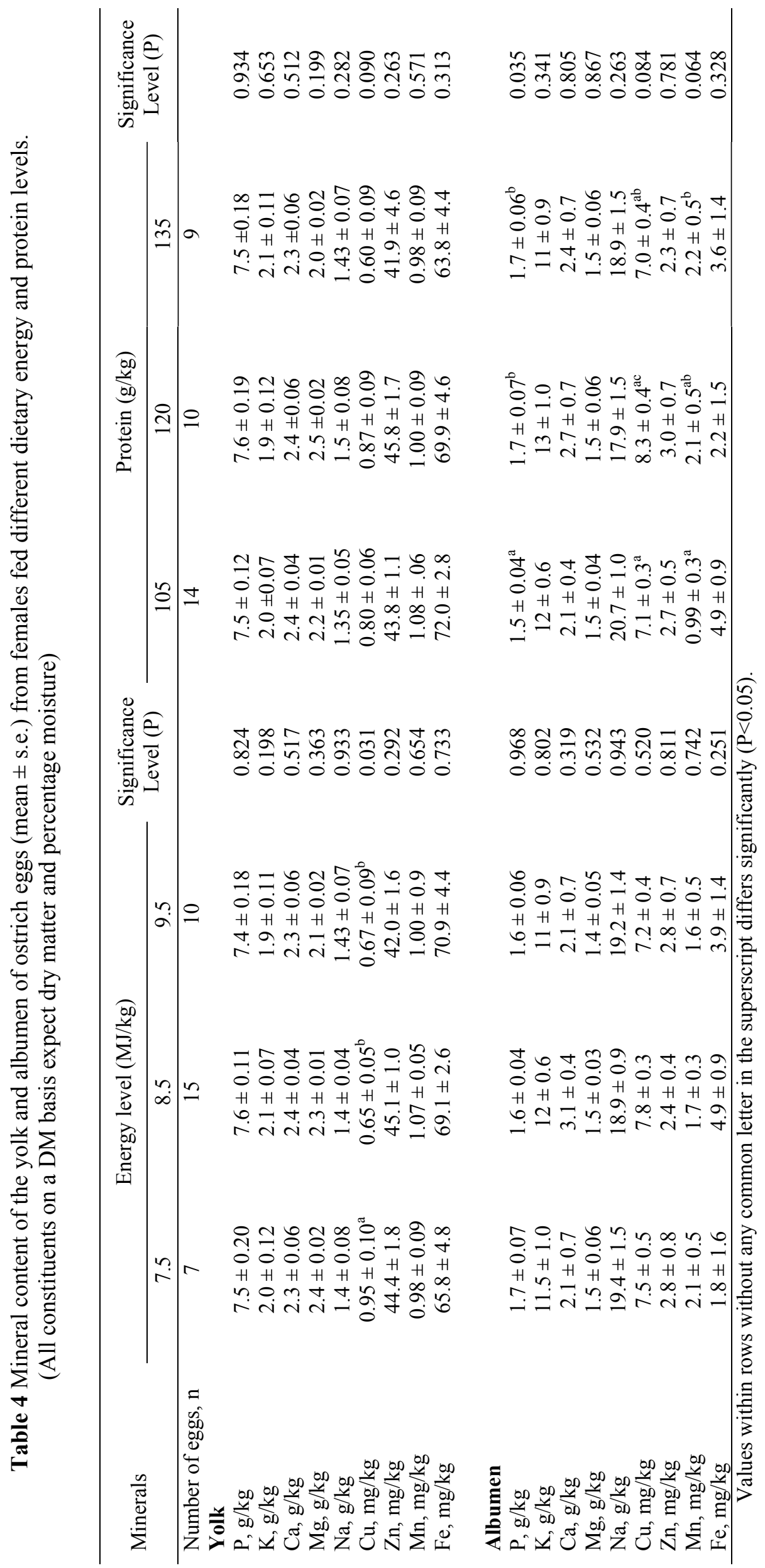

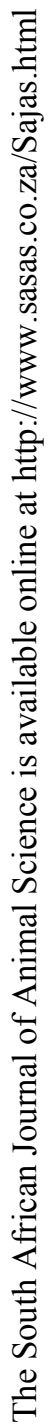


of yolk weight decreased linearly as dietary protein and energy levels increased (Uddin et al., 1997). The different dietary protein and energy levels, however, did not significantly influence eggshell weight, albumen and yolk dry matter, yolk lipid or egg energy content (Uddin et al., 1997).

Apart from general composition of eggs, Naber (1979) and Badley (1997) also found that the concentration of some minerals $(\mathrm{Ca}$ and $\mathrm{P})$ and amino acids are influenced only slightly or not at all by nutrition. This is in line with our own findings on yolk from ostrich breeders fed different dietary levels of protein. We also found that dietary protein did not significantly affect mineral and amino acid composition, whereas different energy levels did appear to have some effect on the amino acid composition of albumen in ostrich eggs. Lopez \& Leeson (1995) found that, although broiler breeders which were fed a low crude protein diet $(10 \mathrm{~g} / \mathrm{kg})$ retained less nitrogen, the nitrogen deposited in the egg was not affected. While the influence of dietary energy levels on amino acid concentrations is not clear, presumably birds fed lowprotein diets meet protein and specific amino acid requirements for egg formation from their diets or, alternately, were able to do so from body protein reserves (Murphy, 1994). The latter suggest that the viability of the egg will be maintained even with low crude protein intake.

Du Preez (1991), Angel (1993) and Sales et al. (1996) have reported values for the composition of ostrich eggs, but these results are not necessarily comparable to this study. Those authors analysed albumen and yolk together, whereas in this study these components were analysed separately. Where comparable data are available, it suggests some variations in the protein composition of the albumen in the case of ratite and chicken eggs. The lipid content of ostrich eggs tends to be lower than that of emu eggs (Angel, 1993) and chicken eggs (Angel, 1993; Sales et al., 1996).

There are no reliable reports of the amino acid profiles of ostrich eggs. Naber (1979) suggests that amino acid composition of eggs is not influenced by diet. We, however, found a tendency for the concentration of some amino acid to be higher in eggs of ostriches fed diets with higher energy levels, although these trends were not evident in birds fed different protein levels. The relationship between dietary energy levels and amino acid concentrations is not clear in general, but the broad amino acid profiles of ostrich eggs appear similar to other species. Murphy (1994) noted that leucine, lysine and valine were the most abundant amino acids in eggs from five species of birds and histidine, methionine and tyrosine were least abundant, a pattern for the most part reflected in ostrich eggs. Ostrich eggs, however, have a higher leucine and threonine content than chicken eggs, and the total quantity of essential amino acids determined in ostrich eggs is higher than that of chicken eggs (Sales et al., 1996). The concentration of the non-essential amino acid alanine is lower in ostrich eggs than in chicken eggs.

Mineral concentrations of $\mathrm{Ca}, \mathrm{Fe}, \mathrm{Mg}$ and $\mathrm{Zn}$ measured in ostrich eggs in the present study were similar to those previously reported by Angel (1993), although concentrations of Mn and P were slightly less. The concentrations of $\mathrm{Ca}, \mathrm{Fe}, \mathrm{Mg}$ and $\mathrm{Zn}$ were also similar to those of chicken eggs, whereas $\mathrm{Mn}$ and $\mathrm{P}$ concentrations were lower (Sales et al., 1996).

Overall, although there were some minor differences in egg composition, amino acid concentration and mineral concentrations in the eggs of ostriches fed diets with different combinations of energy and protein, with accompanied relevant amino acid levels, most of these were not related to dietary energy and protein in any consistent way. We consequently conclude that different dietary energy and protein levels with accompanied relevant amino acid levels, as used in this study, have little or no effects on the composition of ostrich eggs.

\section{Acknowledgement}

Financial assistance of the Klein Karoo Co-operative at Oudtshoorn, Elsenburg Agricultural Centre and the National Research Foundation's THRIP programme is gratefully acknowledged.

\section{References}

Angel, C.R. 1993. Nutrient profiles of ostrich and emu eggs as indicators of nutritional status of the hen and chick. In: Ostrich Odyssey: proceeding of the Meeting of the Australian Ostrich Association Inc. No. 217 (Victoria), Ed. Bryden, D.I., pp. 138-140. Postgraduate Committee in Veterinary Science, University of Sydney.

Association of Official Analytical Chemist International, 1975. Official Methods of Analysis (12th ed.) Washington, DC, Association of Official Analytical Chemists, pg. 1094

Association of Official Analytical Chemist International, 1995. Official method of analysis of AOAC International, (16th ed.), Method 4.5.01 (920.39), AOAC International, Maryland, USA.

The South African Journal of Animal Science is available online at http://www.sasas.co.za/Sajas.html 
Badley, A.R., 1997. Fertility, hatchability and incubation of ostrich (Struthio camelus) eggs. Poultry and Avian Biol. Rev. 8, 53-76.

Barreto, S.L.T. \& Ferreira, W.M., 1999a. Protein and vitamin E levels for broiler breeder hens. 1. Effect on broiler breeder performance, egg composition and performance of their progeny. Arquivo, Brasileiro de Medicina Vetertinaria e Zootecnia. 51, 183-192.

Barreto, S.L.T. \& Ferreira, W.M., 1999b. Protein and vitamin E levels for broiler breed hens. 2. Effect on yolk and tissue alpha-tocopherol concentration and nitrogen balance. Arquivo, Brasileiro de Medicina Vetertinaria e Zootecnia. 51, 193-199.

Brand, T.S., 2000. Electronic Ostrich Feed Databases. Elsenburg Agricultural Research Centre, Private Bag X1, Elsenburg, 7607, South Africa.

Brand, Z., Brand, T.S. \& Brown, C.R., 2003. The effect of dietary energy and protein levels on production in breeding female ostriches. Br. Poult. Sci. (in press).

Carey, C., 1996. Female reproductive energetics. In: Avian Energetics and Nutritional Ecology. Ed. Carey, C., pp. 324-373. Chapman and Hall, New York.

Deeming, D.C., 1997. Ratite Egg Incubation - A Practical Guide. Ratite Conference, Buckinghamshire, UK.

Deeming, D.C., 2002. Embryonic development and utilisation of egg components. In: Avian incubation: behaviour, environment, and evolution. Ed. Deeming, D.C., Oxford University Press, Oxford. pp. 43-53.

Du Preez, J.J., 1991. Ostrich nutrition and management. In: Recent Advances in Animal Nutrition in Australia. Ed. Farrell, D.J., University of New England, Armidale, Australia. pp. 279-292.

Einasson, S., Josefson, B. \& Lagerkvest, S., 1983. Determination of amino acid with 9- fluorenylmetyl chloroformate and reverse phase high performance liquid chromatography. J. Chromatography. 282, 609-618.

Hammershøj, M. \& Kjaer, J.B., 1998. Phase feeding for laying hens: Effect of protein and essential amino acid on egg quality and production. Acta Agric. Scand. Section. A, Anim. Sci. 49, 31-41.

Hanczakowski, P., Szymczyk, B. \& Kuchta, M., 1998. The effect of feed protein on cholesterol and fatty acids contents of hen egg yolk. Roczniki Naukowe Zootechniki. 25, 117-125.

Lopez, G. \& Leeson, S. 1995. Response of broiler breeders to low-protein diets. 1. Adult breeder performance. Poult. Sci. 74, 685-695.

Morris, T. 1985. The manipulation of egg size and egg quality. S. Afr. J. Anim. Sci. 15, 120-122.

Murphy, M.E., 1994. Amino acid composition of avian eggs and tissues. Nutritional implications. J. Avian Biol. 25, 27-38.

Naber, E.C., 1979. Effect of nutrition on the composition of the egg. Poult. Sci. 58, 518-528.

Nager, R.G., Rüegger, C. \& Van Noordwijk, A.J., 1997. Nutrient or energy limitation on egg formation: a feeding experiment in greater tits. J. Anim. Ecol. 66, 496-507.

Noble, R.C., Speake, B.K., McCartney, R., Foggin, C.M. \& Deeming, D.C., 1996. Yolk lipids and their fatty acids in wild and captive ostrich (Struthio camelus). Comp. Biochem. Physiol. 113B, 753-756.

Sales, J., Poggenpoel, D.G. \& Cilliers, S.C., 1996. Comparative physical and nutritive characteristics of ostrich eggs. World's Poult. Sci. J. 52, 45-52.

Spratt, R.S. \& Leeson, S., 1987. Broiler breeder performance in response to diet protein and energy. Poult. Sci. 66, 683-693.

Statgraphics 5.0, 1991. Statistical Graphic System. Statistical Graphics Corporation Inc., 2115 East Jefferson Street, Rockville, MD 20852, pp. 015-033.

Uddin, M.S., Tareque, A.M.M., Khan, M.J., Haque, M.R., Paul, D.C. \& Howlider, M.A.R., 1997. Effect of dietary protein and energy levels on the quality of eggs of cage-reared Starcross layers. Bangladesh J. Sci. Indust. Res. 32, 573-582.

Van Schalkwyk, S.J., 1998. Improvement of fertility and hatchability of artificially incubated eggs in the Little Karoo. MSc thesis, Rhodes University, Grahamstown, South Africa, 106 pp.

Whitehead, C.C., 1989. Nutrition of the breeding bird and developing embryo. In: Avian Incubation. Ed. Tullett, S.G., Butterworth - Heinemann, London. pp. 227-238.

Williams, D.T., 1996. Variation in reproductive effort in female Zebra finches (Taeniopygia guttata) in relation to nutrient-specific dietary supplements during egg laying. Physiol. Zool. 69, 1255-1275. 